\title{
PENAMPILAN PRODUKSI AYAM RAS PETELUR MB 402 YANG DIBERI RANSUM MENGANDUNG MINYAK LIMBAH IKAN CAKALANG (Katsuwonus pelamis L)
}

\author{
Karlia S. Walukow, J. Laihad, Jein Rinny Leke*, M. Montong \\ Fakultas Peternakan Universitas Sam Ratulangi Manado
}

\begin{abstract}
ABSTRAK
Penelitian ini bertujuan untuk mengetahui sampai sejauh mana pemberian minyak Limbah ikan Cakalang (Katsuwonus pelamis L) terhadap penampilan produksi ayam ras petelur MB 402. Materi yang digunakan dalam penelitian ini adalah 100 ekor ayam petelur MB 402 berumur 36 minggu. Perlakuan yang digunakan adalah Ransum Basal (R0), Ransum Basal 99\% + 1\% MLI (R1), Ransum Basal 98\% + 2\% MLI (R2), Ransum Basal 97\% + 3\% MLI (R3), Ransum Basal 96\% + 4\% MLI (R4). Variabel yang diamati meliputi konsumsi ransum (g/ekor), hen day production (\%), konversi. Metode penelitian yang digunakan adalah metode percobaan menggunakan rancangan Acak Lengkap (RAL) dan Uji Jarak Berganda Duncan's, dengan menggunakan 5 perlakuan dengan 5 ulangan dan tiap ulangan terdiri dari 4 ekor ayam petelur MB 402. Hasil penelitian menunjukkan bahwa penggunaan minyak ikan dalam ransum ayam petelur MB 402 tidak berpengaruh nyata $(\mathrm{P}>0.05)$ terhadap konsumsi ransum, HDP dan konversi. Berdasarkan hasil penelitiandapat disimpulkan bahwa penggunaan minyak limbah ikan cakalang (Katsuwonus pelamis L) dalam ransum sebanyak 4\% memberikan hasil yang sama terhadap konsumsi ransum, Hen Day Production, konversi.
\end{abstract}

Kata Kunci : Penampilan produksi, Ayam petelur, Minyak limbah Ikan cakalang

Korespondensi (corresponding author)

email: rinileke@yahoo.com

\section{ABSTRACT}

PRODUCTION PERFORMANCE OF LAYING HENS MB 402 FED RATION COINTAINING OIL OF CAKALANG FISH WASTE (Skipjack Tuna). This study was conducted to determine the production performance of laying hens (MB 402) fed ration containing fish oil waste. The materials used in this study were 100 laying hens at the age of 36 weeks. The treatments used were: $100 \%$ basal feed (R0), basal feed 99 $\%$ with 1\% FOW (R1), basal feed $98 \%$ with $2 \%$ FOW (R2), basal feed $97 \%$ with $3 \%$ FOW (R3), basal feed $96 \%$ with $4 \%$ FOW (R4). Variables observed were including feed consumption (g/bird), Hen Day Production (\%), feed conversion. Method used was the completely randomized design (CRD) continued by Duncan's test for the significant analysis of variance. Treatments were replicated 5 times consist of 4 laying hens per replication. Results showed that the use of fish oil waste had no significant effect $(\mathrm{P}<$ 0.05) on feed consumption, Hen Day Production and feed conversion. Based on the results of this study, it was concluded that use of fish oil waste in the diet as much as $4 \%$ could be recommended in ration to give the sama production performance of laying hens (MB 402).

Keywords: Performance production, laying hens, fish oil waste. 


\section{PENDAHULUAN}

Ayam petelur sudah lama dikenal di masyarakat dan diusahakan sebagai usaha sampingan maupun usaha peternakan. Ayam petelur merupakan ayam yang dipelihara khusus untuk diambil telurnya. Dikarenakan ayam petelur mempunyai potensi yang cukup besar untuk dikembangkan sebagai usaha peternakan karena memiliki kemampuan yang menguntungkan yaitu mempunyai telur yang nilai gizi tinggi dan rasa yang lezat. Telur merupakan produk peternakan yang memberikan sumbangan besar bagi tercapainya kecukupan gizi masyarakat (Sudaryani, 2003). Ayam ras petelur dapat memproduksi telur sekitar 250 - 300 butir per tahun (Sudarmono, 2003).

Pakan merupakan porsi biaya terbesar $(70 \%)$ dalam usaha peternakan unggas. Pakan yang baik adalah pakan yang mengandung gizi yang dibutuhkan oleh ternak unggas sesuai dengan jenis dan bangsa unggas, umur, bobot badan. Jenis kelamin dan fase produksi. Penampilan produksi ayam ras petelur dapat dilihat dari konsumsi ransum, konversi ransum, dan produksi telur. Ransum untuk ayam berproduksi pada komposisi yang baik adalah dengan kandungan protein 17\% dan energinya 2850 kkal/kg. Gunawan (2002) melaporkan dengan kandang baterai dan ransum berprotein $15 \%$ dan ME 2500 $\mathrm{kkal} / \mathrm{kg}$, produksi telur mencapai $48,5 \%$. Sedangkan menurut Tajufri (2013) protein $17 \%$ dan energi $2700 \quad \mathrm{kkal} / \mathrm{kg}$ menghasilkan produksi dan berat telur paling tinggi dibandingkan protein 14\%$16 \%$ dan energi $2400 \mathrm{kkal} / \mathrm{kg}, 2600$ $\mathrm{kkal} / \mathrm{kg}, 2700 \mathrm{kkal} / \mathrm{kg}$. Imbangan energi dan protein penentu terhadap penampilan produksi ayam, karena naluri ayam akan berhenti makan bila kebutuhan energinya terpenuhi. Dalam upaya peningkatan produksi telur, ternak unggas harus diberi pakan yang bergizi dan sesuai kebutuhan. Pemberian pakan yang baik tentunya akan berpengaruh terhadap produksi telur, konsumsi ransum, dan juga angka konversi dari pakan yang diberikan. Jadi dengan adanya keseimbangan antara energi dan protein yang tepat maka pernampilan produksi yang dihasilkan ayam akan optimal. Pakan dalam usaha peternakan unggas memiliki peranan pokok yang perlu mendapat perhatian selain bibit dan manajemen. Salah satu penunjang optimalisasi pertumbuhan ayam petelur adalah kebutuhan energi. Kebutuhan energi yang tinggi untuk ayam petelur sulit dipenuhi apabila hanya memaidalam saluran pemanfaatkan bahan pakan bijibijian saja.Salah satu pakan unggas yang kerap kali digunakan pada pakan unggas ayam petelur sebagai sumber energi adalah 
minyak ikan. Pakan yang mengandung lemak/ minyak ikan akan dicerna di dalam saluran pencernaan unggas menjadi asamasam lemak seperti asam lemak linoleat, linoleat termasuk Omega 3 (EPA dan DHA) yang juga dibutuhkan manusia (Scott et al., 1982)

Minyak ikan adalah minyak yang berasal dari jaringan ikan yang berminyak. Minyak ikan banyak tersedia di Indonesia negara kepulauan yang mempunyai lautan luas. Provinsi Sulawesi Utara memliki potensi menghasilkan minyak ikan dari limbah pengalengan ikan dengan adanya pabrik pengalengan ikan dan pabrik ikan beku yang diekspor. Jumlah produksi dan nilai produksi jenis ikan Cakalang tahun 2011 yaitu 60.158,8 ton (Dinas Perikanan dan kelautan Provinsi Sulawesi Utara. 2012). Perusahaan Perikanan PT Nichindo di Kabupaten Minahasa mengolah Ikan Cakalang untuk ekspor ikan beku dan pengolahan ikan kayu. Seiring perkembangan industri pengolahan ikan, jumlah limbah yang dihasilkan semakin meningkat. Limbah tersebut dimanfaatkan kembali apabila mengalami proses pengolahan lebih lanjut. Limbah industri perikanan ada yang termanfaatkan dan ada yang terbuang, namun dengan inovasi teknik pengolahan dapat digunakan sebagai pakan ayam petelur.

Minyak ikan merupakan salah satu sumber asam lemak tak jenuh rangkap banyak terutama asam lemak omega-3 yang dapat digunakan untuk meningkatkan asam lemak omega-3 pada ternak, sehingga produk ternak yang dihasilkan mengandung asam lemak omega-3. Minyak ikan dapat digunakan untuk meningkatkan asam lemak omega -3 kuning telur pada ayam petelur. Minyak ikan banyak mengandung vitamin A dan D, pigmen karotenoid, omega 3 PUFA, asam lemak Eicosapentanoat (EPA) dan asam dokosaheksanoat (DHA) yang dibutuhkan ayam petelur dalam memproduksi dan pembentukan telur (Hargis et al., 1993; Van Elswyk et al., 1992; Sudibya, 1998; Gonzales dan Lesson, 2000). Minyak bisa dijadikan sebagai sumber energi pada pakan unggas (Bess et al., 2011), begitu pula dengan minyak ikan. Selain itu, minyak juga bermanfaat membantu vitamin-vitamin yang larut dalam lemak serta mengurangi sifat berdebu dalam pakan (Franz et al., 2010). Umumnya kadar vitamin dalam minyak ikan berkisar antara 1.000 1.000.000 SI (standar international) per gram, sementara vitamin D sekitar 50 30.000 SI per gram.

Hasil samping industri pengalengan ikan yang cukup banyak dan pemanfaatannya belum optimal dan berpotensi sebagai sumber asam lemak omega-3. Salah satu limbah minyak ikan yang tersedia adalah limbah minyak ikan 
cakalang (Katsuwonus pelamis L).

Minyak ikan merupakan salah satu alternatif yang dapat dijadikan sebagai pakan sumber energi. Pemanfaatan minyak limbah ikan sebagai pakan ternak terutama unggas petelur dilakukan dengan tujuan untuk mendapatkan produk ternak yang tinggi dan kualitas telur yang baik. Dari pemikiran ini maka dilakukan penelitian dengan judul "Penampilan Produksi Ayam Ras Petelur MB 402 Yang Diberikan Ransum Mengandung Minyak Limbah Ikan Cakalang ( Katsuwonus pelamis L)”.

\section{MATERI DAN METODE PENELITIAN}

\section{Materi Penelitian}

Materi yang digunakan dalam penelitian ini adalah ayam ras petelur fase layer MB 402 yaitu umur 36 minggu sebanyak 100 ekor. Pada perusahaan peternakan ayam petelur. PT .Ko Gunawan Kayuwatu Kota Manado. Kandang yang digunakan adalah kandang battery yang terbuat dari kawat dengan ukuran $60 \quad$ x $30 \quad$ x $35 \quad \mathrm{~cm}$. Secara keseluruhan kandang battery dilengkapi tempat pakan dan tempat minum yang terbuat dari pipa dibelah menjadi dua bagian. Bahan pakan yang digunakan terdiri dari jagung kuning, dedak halus, tepung ikan, $\mathrm{CaCO}_{3}$, konsentrat Cal 19. Sebanyak 36 ayam layer dan minyak limbah ikan yang disusun berdasarkan kebutuhan zat zat makanan untuk ayam petelur. Sedangkan minyak limbah ikan cakalang diperoleh dari perusahaan perikanan PT Nichindo Kabupaten Minahasa. Proses Pengolahan minyak limbah ikan cakalang dapat dilihat pada Gambar 1. Kandungan zat bahan makanan pakan dapat dilihat pada Tabel 1, komposisi ransum dan zat-zat makanan pakan perlakuan pada penelitian ini dapat dilihat pada Tabel 2 dan Tabel 3.. Pengamatan dilakukan selama 8 minggu.

\section{Metode Penelitian}

Rancangan percobaan yang digunakan dalam penelitian ini adalah rancangan acak lengkap (RAL) (Steel dan Torrie, 1994). Perlakuan yang dilakukan sebanyak 5 perlakuan dan 5 ulangan sehingga terdapat 25 unit perlakuan, dimana pada masing - masing unit terdiri dari 4 ekor ayam petelur MB 402, sehingga jumlah ayam yang digunakan 100 ekor. Perlakuan disusun berdasarkan iso energi dan iso protein sesuai dengan perlakuan sebagai berikut : 


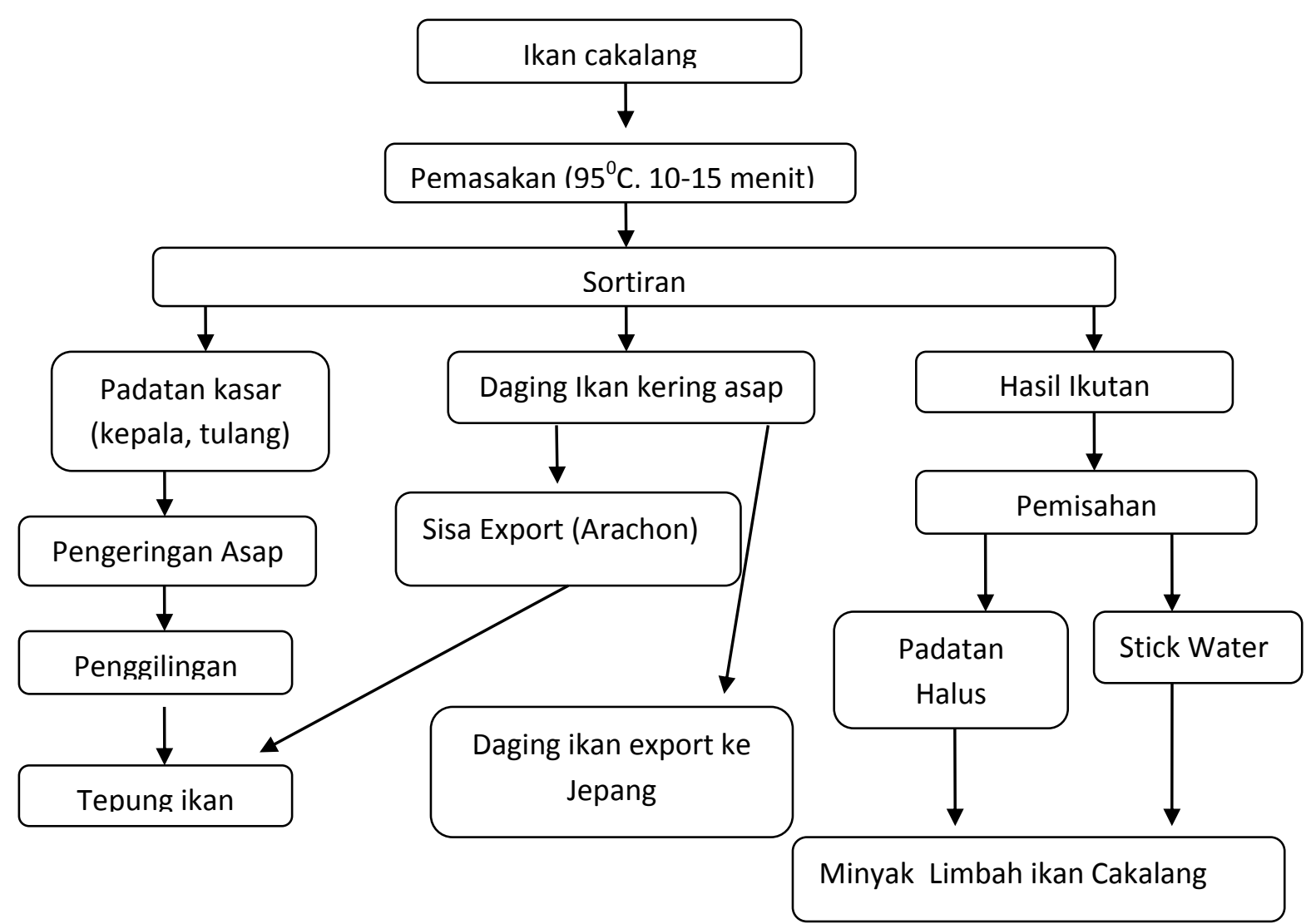

Gambar 1. Proses limbah ikan cakalang (Katsuwonus pelamis L) PT. Nichindo Manado Suisan, Amurang Minahasa Selatan Provinsi Sulawesi Utara (2011)

Minyak limbah ikan cakalang yang digunakan pada penelitian pakan sesuai perlakuan sebagai berikut :

$\mathrm{R} 0=$ Ransum Basal

$\mathrm{R} 1=$ Ransum Basal 99\% + 1\% minyak limbah ikan cakalang (MLIC)

$\mathrm{R} 2=$ Ransum Basal 98\% $+2 \%$ MLIC

R3 = Ransum Basal 97\% + 3\% MLIC

R4 = Ransum Basal 96\% + 4\% MLIC

Prosedur Pembuatan Minyak Limbah Ikan

Cakalang dapat dilihat pada Gambar 1.

\section{Variabel yang diamati :}

Variabel yang diamati dalam penelitian ini adalah

1. Konsumsi ransum dihitung dengan cara menimbang sejumlah pakan yang diberikan (gram) dikurangi sejumlah pakan yang tersisa (gram) yang dilakukan setiap 24 jam sekali (Anggorodi, 1985; Leke, 2016). 
Tabel 1. Komposisi Zat-zat dan Bahan Pakan Penyusun Ransum

\begin{tabular}{|c|c|c|c|c|c|c|}
\hline Bahan pakan & Protein & SK & Lemak & $\mathrm{Ca}$ & $\mathrm{P}$ & Energi \\
\hline Jagung kuning $^{1)}$ & 9.42 & 2.15 & 5.17 & 0.22 & 0.6 & 3182 \\
\hline Dedak $^{1)}$ & 12 & 12 & 13 & 0.12 & 0.5 & 1630 \\
\hline Tepung Ikan ${ }^{1)}$ & 60 & 1 & 9 & 5.5 & 0.33 & 2830 \\
\hline $\mathrm{CaCO}_{3}^{2)}$ & 0 & 0 & 0 & 29.4 & 0 & 0 \\
\hline Konsentrat Cal 9.36 & 29 & 7 & 10 & 3 & 2 & 2600 \\
\hline Minyak limbah ikan ${ }^{3)}$ & 2.14 & 0 & 20.44 & 0.87 & 0.85 & 6300 \\
\hline
\end{tabular}

Ket : ${ }^{1)}$ NRC (1994).

2) Sumber PT. Japfa

${ }^{3)}$ Hasil analisa menurut Leke et al. (2015)

Tabel 2. Komposisi Ransum Perlakuan

\begin{tabular}{|c|c|c|c|c|c|c|}
\hline \multirow[t]{2}{*}{ Bahan Makanan } & Jagung & Dedak & Kor & atCal & $\begin{array}{c}\text { Tepung } \\
\text { Ikan }\end{array}$ & $\mathrm{CaCO} 3$ \\
\hline & \multicolumn{6}{|c|}{$(\%)$} \\
\hline Jumlah (100) & 52 & 14 & & & 7 & 3 \\
\hline \multirow{2}{*}{ Jenis Bahan Pakan } & \multicolumn{6}{|c|}{ Jumlah Menurut Perlakuan (\%) } \\
\hline & & R0 & R1 & $\mathrm{R} 2$ & R3 & $\mathrm{R} 4$ \\
\hline Ransum Basal & & 100 & 99 & 98 & 97 & 96 \\
\hline Minyak limbah ikan & & 0 & 1 & 2 & 3 & 4 \\
\hline Total & & 100 & 100 & 100 & 100 & 100 \\
\hline
\end{tabular}

Tabel 3. Komposisi Zat-zat Makanan Ransum Perlakuan

\begin{tabular}{lrrrrr}
\hline \multicolumn{1}{c}{ Komposisi zat-zat makanan } & \multicolumn{1}{c}{$\mathrm{R}_{0}$} & \multicolumn{1}{c}{$\mathrm{R}_{1}$} & \multicolumn{1}{c}{$\mathrm{R}_{2}$} & \multicolumn{1}{c}{$\mathrm{R}_{3}$} & \multicolumn{1}{c}{$\mathrm{R}_{4}$} \\
\hline Protein & 17,73 & 17,57 & 17,42 & 17,26 & 17,11 \\
Serat Kasar & 4,5 & 4,46 & 4,41 & 4,37 & 4,32 \\
Lemak & 6,9 & 7,04 & 7,17 & 7,31 & 7,44 \\
$\mathrm{Ca}$ & 2,33 & 2,32 & 2,3 & 2,29 & 2,27 \\
$\mathrm{P}$ & 0,73 & 0,73 & 0,73 & 0,73 & 0,73 \\
Energi Metabolis & $2.704,94$ & $2.740,89$ & $2.776,84$ & $2.812,79$ & $2.848,74$ \\
\hline
\end{tabular}

Keterangan: Hasil perhitungan berdasarkan Tabel 1 dan 2. 
Konsumsi pakan setiap minggu kemudian dijumlahkan untuk mengetahui konsumsi pakan total selama penelitian.

2. Produksi telur harian (Hen Day Production): Presentase dari total telur yang diproduksi oleh sejumlah ayam dalam kurun waktu tertentu (Dadang, 2006, Leke 2015)

3. Konversi ransum dihitung berdasarkan rumus (Olgun et al (2009)

$$
\text { Konversi }=\frac{\text { Konsumsi ransum }\left(\frac{\mathrm{g}}{\text { ekor }} / \text { hari }\right)}{\text { Egg mass }\left(\frac{\mathrm{g}}{\text { ekor }} / \text { hari }\right)}
$$

\section{HASIL DAN PEMBAHASAN}

Pengaruh penggunaan minyak limbah ikan cakalang (katsuwonus pelamis L) terhadap konsumsi ransum (g/ekor), HDP (\%) dan konversi dapat dilihat pada Tabel 4.

\section{Pengaruh Perlakuan Terhadap Konsumsi Ransum}

Nilai rata rata konsumsi ransum penelitian ini berkisar antara 99,76 110,31 g/ekor. Anggorodi (1985) bahwa ayam petelur berumur diatas 5 bulan mengkonsumsi ransum 100 - 125 gram per ekor per hari.

Berdasarkan hasil analisis ragam menunjukkan bahwa penggunaan minyak limbah ikan dalam pakan ayam petelur MB 402 memberikan pengaruh tidak nyata $(\mathrm{P}>0,05)$ terhadap konsumsi ransum. Berarti bahwa penggunaan minyak limbah ikan cakalang sampai level 4\% tidak mempengaruhi konsumsi ransum. Hal ini disebabkan karena kandungan protein kasar dari kelima perlakuan memiliki iso energi dan iso protein $17 \%$ dan energi metabolis $2700 \mathrm{Kkal} / \mathrm{kg}$. Scott et al. (1992) menyatakan bahwa imbangan antara protein dan energi dalam ransum mempengaruhi jumlah konsumsi ransum. Menurut Kartasudjana dan Suprijatna (2006), ayam mengkonsumsi ransum untuk memenuhi kebutuhan energinya. Jika kebutuhan energi belum terpenuhi ayam akan terus makan. Sebaliknya, bila energi dalam ransum tinggi, maka ayam akan mengurangi konsumsinya. Minyak ikan juga mengandung energi yang lebih besar sebagai sumber energi lain, dan penggunaan dalam ransum akan meningkatkan energi ransum (Amrullah, 2004). Selanjutnya Sestilawarti (2011) menyatakan ini disebabkan karena penambahan minyak ikan akan menyebabkan palatabilitas ransum menurun sehingga konsumsi ransum menurun. Dikarenakan pemberian minyak ikan secara langsung dalam ransum menemukan beberapa kendala diantaranya 
Tabel 4. Pengaruh Pengunaan Minyak Limbah Ikan Cakalang Terhadap Konsumsi Ransum, Hen Day Production Dan Konversi Ayam Petelur MB 402.

\begin{tabular}{llll}
\hline Perlakuan & \multicolumn{3}{c}{ Variabel } \\
\cline { 2 - 4 } & $\begin{array}{l}\text { Konsumsi } \\
\text { Ransum(g/ekor) }\end{array}$ & HDP(\%) & Konversi \\
\hline RO & $103,60 \pm 3,86$ & $83,22 \pm 5,25$ & $2,23 \pm 0,04$ \\
R1 & $110,31 \pm 2,87$ & $88,75 \pm 4,67$ & $2,19 \pm 0,11$ \\
R2 & $104,00 \pm 5,66$ & $79,37 \pm 6,24$ & $2,34 \pm 0,05$ \\
R3 & $103,44 \pm 7,10$ & $83,94 \pm 9,29$ & $2,10 \pm 0,06$ \\
R4 & $99,76 \pm 6,59$ & $73,93 \pm 10,96$ & $2,42 \pm 0,27$ \\
\hline
\end{tabular}

Keterangan: Konsumsi Ransum, HDP, Konversi tidak berbeda nyata ( P > 0,05)

sukar dalam pencampuran ke dalam ransum karena membuat ransum menggumpal dan tidak homogen, disamping itu kesulitan dalam penanganan minyak ikan tersebut dalam pendistribusian maupun penyimpanan karena minyak ikan tersebut mudah teroksidasi, dapat menimbulkan bau amis baik pada ransum maupun telur yang dihasilkan, sehingga mempengaruhi palatabilitas ransum. Forbes (1986) menyatakan bahwa peningkatan lemak dapat menurunkan konsumsi pakan, sedangkan Brue dan Latshaw (1985) menyatakan bahwa perbedaan komposisi asam lemak juga mempengaruhi konsumsi pakan. Selanjutnya Tillman et al. (1986) menyatakan, bila kandungan protein dalam ransum cukup dan seimbang maka akan memberikan pengaruh yang sama terhadap konsumsi ransum. Suprijatna et al. (2005) menjelaskan bahwa banyak sedikitnya ransum yang dikonsumsi ternak tergantung juga pada kualitas bahan pakan yang dipergunakan untuk menyusun ransum, keserasian komposisi ransum, nilai nutrisinya sesuai dengan kebutuhan untuk pertumbuhan dan produksi yang optimal serta dipelihara dalam kondisi yang sama.

\section{Pengaruh Perlakuan Terhadap Hen Day Production}

Berdasarkan data pada Tabel 4 dapat diketahui rata rata Hen Day Production dari yang tertinggi R1 $(88,75 \%)$, dan terendah produksi telur $\mathrm{R} 4$ (73,93\%). Pada penelitian ini rataan produksi telur pada saat puncak produksi adalah $88,75 \%$. Angka penelitian dengan kisaran Hen Day Production antara 73,93 - 88,75 \% masih berada pada produksi yang maksimal. Amrullah (2003) menyatakan bahwa ayam petelur unggul 
dapat berproduksi sampai $70 \%$ atau 275 butir per tahun. Hal ini tidak sesuai dengan penelitian yang dilakukan Golden et al. (2012) yang melaporkan bahwa produksi telur ayam ras petelur berkisar $77 \%$ sampai dengan $82 \%$ namun dengan presentase sistem intensif lebih tinggi

Berdasarkan hasil analisis menunjukkan bahwa Hen Day Production menunjukkan bahwa penggunaan minyak limbah ikan dalam pakan tidak memberikan pengaruh tidak nyata ( $\mathrm{P}$ $>0,05)$ terhadap Hen Day Production. Astuti dan Suwiningsih (2010) bahwa indikator penentu produktifitas telur banyak dipengaruhi oleh kandungan nutrisi pakan, konsumsi pakan, dan umur. Suprijatna (2005) menyatakan bahwa presentase produksi pada saat periode produksi nyata dipengaruhi oleh taraf protein selama periode produksi. Hal ini sejalan dengan Agustina dan Puswanti, (2012) menyatakan bahwa untuk memproduksi telur yang tinggi, dalam ransum harus tersedia : protein, energi, lemak, vitamin, mineral dan air. Suthama (2005) menyatakan bahwa, tinggi rendahnya konsumsi protein dan energi akan berpengaruh pada jumlah telur yang dihasilkan.

Menurut Gunawan dan Sihombing (2004), pada suhu lingkungan yang tinggi diperlukan lebih banyak pengaturan suhu tubuh, sehingga mengurangi penyediaan energi untuk produksi telur. Penggunaan minyak limbah ikan sampai level $4 \%$ mengurangi palatabilitas dalam ransum menyebabkan penurunan konsumsi ransum. Konsumsi ransum akan mempengaruhi produksi telur, jika konsumsi sedikit maka produksi telur akan menurun. Dikarenakan minyak ikan menimbulkan aroma yang tidak sedap.Sejalan dengan pendapat Amrullah (2003) bahwa penerimaan unggas terhadap makanan dipengaruhi oleh tekstur, rasa, dan bau.

Kurang optimalnya produksi telur dikarenakan oleh factor-faktor lain seperti genetik dari ayam ras petelur. Sehubungan yang dikemukakan Rasyaf (2009) yang menyatakan bahwa secara genetis tiap unggas mempunyai batas kemampuan maksimal dalam berproduksi. Dalam kondisi lingkungan yang baik dan sesuai dengan yang dibutuhkan (sebab lingkungan yang baik belum tentu yang dibutuhkan oleh unggas tertentu), maka produksi telur akan sampai pada kemampuan produksi menurut genetisnya, tidak akan lebih dari itu.

\section{Pengaruh Perlakuan Terhadap Konversi Ransum}

Pengaruh perlakuan Minyak Limbah Ikan terhadap konversi ransum 
dapat dilihat pada Tabel 4. Berdasarkan data pada Tabel 4, konversi ransum R0 (2,23), R1 (2,19), R2 (2,34), R3 (2,10) dan R4 (2,42). Untuk mengetahui pengaruh perlakuan, maka dilakukan analisi statistik. Konversi pakan ayam petelur selama periode telur pertama maupun kedua berkisar antara 2,0 - 3,0 (Scott et al., 1992).

Berdasarkan analisis statistik menunjukkan bahwa penggunaan minyak limbah ikan pada ransum ayam ras petelur MB 402 tidak memberikan pengaruh nyata $(\mathrm{P}>0,05)$ terhadap konversi ransum. Penggunaan minyak limbah ikan dalam pakan tidak memiliki perbedaan terhadap konversi ransum.Konversi pakan merupakan salah satu ukuran yang banyak digunakan untuk menyatakan tingkat efisien pemanfaatan pakan oleh ternak yaitu perbandingan antara pakan yang dimakan dalam menghasilkan sejumlah telur. Konversi ransum dihitung setiap minggu dengan cara membandingkan jumlah pakan (g) yang dikonsumsi dengan massa telur setiap minggu.

Dengan pengertian bahwa pemanfaatan minyak ikan dengan level $4 \%$ dalam ransum tidak menyebabkan perbedaan terhadap konversi ransum. Tingginya nilai konversi ransum pada perlakuan $\mathrm{R} 4=2,42$ menunjukkan bahwa ayam petelur pada pelakuan ini kurang efisien dalam penggunaan ransum untuk kebutuhan produksi dan pembentukan telur. Konversi ransum dapat digunakan sebagai gambaran koefisien produksi, semakin kecil nilai konversi semakin efisien penggunaan ransum. Puspita (2008) menjelaskan bahwa konversi ransum erat kaitannya dengan konsumsi ransum dan produksi telur. Semakin rendah nilai konversi ransum yang diperoleh, maka semakin efisien ternak. Hal ini didukung oleh pendapat Anggorodi (1994) yang menyatakan bahwa tinggi rendahnya konversi ransum sangat ditentukan oleh keseimbangan antara energi metabolisme dengan zat-zat nutrisi terutama protein dan asam-asam amino.

Konversi pakan yang tinggi pada pakan lebih disebabkan karena konsumsi pakan yang rendah yang menyebabkan kecukupan asupan zat makanan ayam untuk memproduksi telur menjadi sedikit lebih rendah. Nuraini et al. (2008) yang mendapatkan konversi ransum ayam petelur sebesar 2,55 dengan pemberian $60 \%$ onggok dan $40 \%$ ampas tahu yang difermentasi dengan Neurospora crassa pada ayam petelur berumur $28-36$ minggu.

\section{KESIMPULAN}

Berdasarkan hasil penelitian dapat disimpulkan bahwa penggunaan minyak 
limbah ikan cakalang (Katsuwonus pelamis $L$ ) dalam ransum ayam ras petelur MB 402 pada taraf 1 - 4\% memberikan hasil yang sama tehadap konsumsi ransum, produksi telur dan konversi ransum.

\section{DAFTAR PUSTAKA}

Amrullah, I. K. 2003. Nutrisi Ayam Petelur. Seri Beternak Mandiri. Lembaga Satu Gunungbudi, Bogor.

Anggorodi, H. R. 1985. Kemajuan Mutahir Dalam Ilmu Makanan Ternak Unggas. Universitas Indonesia. Jakarta.

Anggorodi, H. R. 1994. Ilmu Makanan Ternak Unggas. Penerbit PT. Gramedia, Jakarta.

Astuti, P dan Suwiningsih. 2010. Produk si telur ayam arab yang mendapa tkan pakan dengan suplementasi temu ireng. Majalah Ilmiah Volume 15 No. 2.

Bess, F., A. Favero, S. L. Vieira and J. Torrent. 2012. The effect of functional oil on broiler diets of varying energy levels. J. Appl. Poult. Res. 21: 567-578

Dadang, R. A. 2006. Effect of rice bran and phytase supplementation on egg laying performance and egg quality of laying hens. Thesis. University Putra Malaysia.

Franz, C., K. H. C Baser and W. Windisch. 2010. Essential oils and aromatic plants in animal feeding - a European perspective. A review. Flavour Fragr. J. 25: 327-340.

Gonzalez-Esquerra, $\mathrm{R}$ and S. Lesson.
2000. Effect of feeding hens regular or do-dorized menhaden oil on production parameters yolk fatty acid profile, and sensory quality of eggs. Poult Sci 79:15971602.

www.ncbi.nlm.gov/pubmed/11128 390. Tanggal akses 20 November 2016

Gunawan dan D. T. H. Siombing. 2004. Pengaruh suhu lingkungan tinggi terhadap kondisi fisiologis dan produktivitas ayam buras. Wartazoa.14(1): 31-38.

Hargis, P.S., M. E. Van Elswyk. 1993. Manipulating the fatty acid composition of poultry meat and eggs for the health conscious consumer.World's Poult. Sci. J. 49:251-264.

Kartasudjana, R. dan E Suprijatna. 2006. Manajemen Ternak Unggas. Penerbit Penebar Swadaya. Jakarta.

Leke, J.R. 2015. Kualitas External Dan Internal Telur Ayam Kampung Yang diberi Pakan Limbah Ikan Cakalang (Katsuwonus pelamis L). ISBN. $\quad 978-979-3660-20-2$. Universitas Sam Ratulangi. Unsrat Press.

Leke, J.R., Vonny Rawung, J. Laihad, W. Utiah, J.S Mandey. 2015. Penampilan produksi ayam kampung yang diberi ransum mengandung minyak ikan. Prosiding. Seminar Nasional Peternakan Berkelanjutan. Unpad Bandung. Hal: 27-31. http://peternakan.unpad.ac.id

National Research Council. 1994. Nutrient Requirements of Poultry. Eighth Revised Edition . National Academy of Sciences. Washington.DC. 
Nuraini, Sabrina and S. A. Latif. 2008. Performa ayam dan kualitas telur yang menggunakan

Olgun, O., Y. Cudafar and A. O. Yildiz. 2009. Effect of boron supplementation feed with low calcium to diet performance and egg quality in method laying hens, J. Anim. Vet adv. S(4) 650-654. Ducdrive/com/pdfs/medwel/journa 1s/java/2009/650-654/pdf.

Accessed: 4 September 2015.

Puspita. 2008. Performa ayam ras petelur periode produksi yang diberi ransum rendah kalsium dengan penambahan zeolit. Skripsi. Fakultas Peternakan. Institut Pertanian Bogor.

Scott, M. L., M. C. Nesheir and R. J. Young. 1982. Nutrition of The Chicken. M. L. Scott and Asociation. Itacha New York.

Steel, R. G. D. dan J. H. Torrie. 1995. Prinsip dan prosedur Statistika Biometrik. PT. Gramedia, Jakarta. Terjemahan: Sumantri.

Sudarmono, A. S., 2003. Pedoman Pemeliharaan Ayam Petelur. Kanisius.

Suthama, N. 2005. Respon Produksi Ayam Kampung Petelur Terhadap Ransum Memakai Dedak Padi Fermentasi dengan Suplementasi Sumber Mineral. Jurnal Indonesia Tropica Animal Agriculture. Hal: $116-121$.

Sudibya. 1998. Manipulasi kadar kolestrol dan asam lemak omega-3 telur ayam melalui penggunaan kepala udang dan minyak ikan lemuru. Disertasi. Program Pascasarjana Institut Pertanian Bogor.

Suprijatna, E. 2005. Pengaruh protein ransum saat periode pertumbuhan terhadap performans produksi telur saat periode produksi pada ayam ras petelur tipe medium. J.Indon.Trop.Anim.Agric. Fakultas Peternakan. Universitas Diponegoro. Semarang

Tillman, A.P., H. Hartadi, S. Reksohadiprodjo, S. Prawirokusumodan S. Lebdosoekodjo. 1986. Ilmu Makanan Ternak Dasar. Gadjah Mada University Press. Yogyakarta.

Triyanto.2007. Performa Produksi Burung Puyuh (Cortunix cortunix japonica) Periode Produksi Umur 6-13 Minggu Pada Lima Pencahayaan Yang Berbeda.[Skripsi]. Fakultas Peternakan. Institut Pertanian Bogor, Bogor.

Van Elswyk, M E., A.R. Sam, P.S. Hargis. 1992. Composition, functionality, and sensory evalution of eggs from hens fed dietray menhaden oil. J. Food Science 57; 342-344. 